DOI: 10.36868/ejmse.2021.06.01.052

\title{
DESIGN AND FABRICATION OF AMUSEMENT PARK TRAIN POWERED WITH ELECTRICITY
}

\author{
Reuben Adebare ADEWUYI ${ }^{1, *}$, Samuel Omojola EJIKO ${ }^{1}$, Dayo Hephzibah OLADEBEYE ${ }^{1}$ \\ ${ }^{1}$ Mechanical Engineering Department, The Federal Polytechnic, Ado-Ekiti, Ekiti State, Nigeria
}

\begin{abstract}
Experience builds and proves the worth of the individual in the field of engineering as a profession. The work centered on the design, fabrication, and testing of electrically operated amusement park train with a remote control unit and electromechanical system. Materials used in the fabrication were sourced locally. The machine design incorporates base frame and bearing/shaft housing as a unit, variable electric motor, $5 \mathrm{hp}(12 \mathrm{rpm})$, coach, lever arm and remote control switch. The design takes care of the speed of the coach with respect to the speed of variable electric motor. The coach is of rectangular form made with an angular bar which is supported by four tyres at the chassis tilted at an angle. Performance evaluation was carried out on the amusement park train and the results showed that the amusement park train has an efficiency of $67.67 \%$. The amusement park train is a viable design, very strong, and efficient. The machine is cheap to install, operate, and maintain. The maintenance does not require special training and spare parts are cheap to obtain. The amusement park train is simple and can be easily operated by the passenger on the coach.
\end{abstract}

Keywords: material selection; design; strength; durability testing.

\section{Introduction}

Technology is the major phenomenon, which is being focused on by all nations in the world today. Hence, there is a need to improve on the existing basic machines. The need for improvement and advancement on such machines is necessary so as to meet the ever-increasing demand and sophistication of the society [1].

Amusement park train is developed for pleasure garden, located outside or inside cities. Pleasure garden provides outdoor congregational space for people and for picnics. The amusement park, a particularly county carnival form, serves two major functions; a way of using general engineering principles in constructing a park using locally sourced material and providing a relaxation center for people [2,3].

This form of outdoor entertainment is developed from long-standing roots. The entertainment certainly reflects the beliefs and concerns of the operator and customers but generally was not motivated by fun and profit, carnivals, freak shows, this amusement park train is a form of electric vehicle $[4,5]$. Conducting a competition at an amusement park has been a great experience for both the students who participate and the organizing team. This exciting experience is enhanced by a significant amount of media attention each year where participating students are celebrated in their local community [6,7].

The electric vehicle project was started with the donation of an MG Midget car from Will Doolittle with the stipulation that the MG be converted to run on electric power. The outline of the project was to work on turning a noisy, smelling, gas-burning car into a quiet, clean, smooth-running electric car $[8,9]$. 
The original goal of the electric vehicle project was to convert a car to an electric vehicle and show the viability of electric vehicles (EVS) as $97 \%$ clean, quiet than gas-powered cars, and require less maintenance than the latter. With the use of $20 \mathrm{HP}$ (60HP Max) electric motor connected to the standard transmission system of electric vehicles, for the amusement park train, reduced horse power is used for the power transmission system or variable electric motor. A 5HP variable electric motor is used in this electromechanical system. This system transforms an electrical process into a mechanical process. The machine is a portable type one, which consists of; variable electric motor 5HP, Vertical shaft, Base frame and bearing housing, lever arm, coach (four-wheel coach on track). Remote control switch, concrete (foundation). The variable electric motor (5hp) is powered by the PHCN source. It transmits power to the vertical shaft at the lower end, coupled to the shaft by a plain coupling [10]. Power transmition depends on good shaft alignment which will increase longevity of the system, hence rigid coupling is required for proper alignment; shaft misalignment will affect the coupling's performance as well as its life. The design is based on $5 \mathrm{hp} \mathrm{(12rpm).}$

\section{Methodology}

This section of the work deals with some of the assumptions made for the various design parameters, design considerations for the efficient performance of the machine, and the design calculation of the component parts of the machine. In machine design and fabrication, there are factors that are considered as well as assumptions. Some of these factors are in size or area of the machine to be designed, material selection with respect to its properties and availability; load to be overcome by the machine, the safety of operation, etc. However, in this work, material selection, machine fabrication and assembly, and its operation were carefully done bearing in mind the operation of the machine $[11,12]$.

\section{Material selection and component parts description}

The selection of material for the fabrication of various component parts was carefully carried out to obtain the best result and long-life expectancy from the machine. The procedures were based on the different functions each part is to play in the proper functioning of the system. Other factors considered in selecting the materials are the availability of the materials and the economic cost of the machine. The component parts and materials selected for each are therefore discussed.

Base Frame and Bearing Housing: The base frame is of square form as shown in Fig. 1. It is made with a thick rectangular steel tube by welding. The bearing housing is a hollow pipe (circular). It is made with a thick round pipe. The bearing housing is fixed upright at the center of the base frame with four thick rectangular steel tubes welded to it at its lower end. Two taper roller bearing resisting an external thrust at both ends of the shaft inside the bearing housing. The base frame and bearing/shaft housing is a unit fixed down with four foundation bolts and nuts of M20 x 300mm one at each corner of the rectangular base frame.

Shaft and Key: Shaft transmits power vertically from the variable electric motor to the lever arm and directly to the tires of the coach. The Shaft is made of a solid rod, high carbon steel, machined to normal size.

The shaft is stepped from both ends of the position of the two bearings. There are keyways at both ends of the shaft, where the key will sit between the shaft and plain coupling. Keys are used on shafts to secure rotating elements such as gears, pulleys; coupling, and other wheels. The keys are used to enable the transmission of torque from the shaft to the shaft supported element. In this kind of design, rectangular keys are used. This key is made of special steel.

Lever Arm: The lever arm is of straight form. It is made with a thick square steel tube. The two ends of the lever arm are fixed to the upper end of the shaft, with bolts and nuts, and to coach with bolts and nuts too. The two ends are fixed rigidly to avoid too much vibration of the parts.

Coach: The coach is of rectangular form, it is made with angular bar, which is supported by four tyres at the chassis tilled at an angle to be able to merry-go-rounds. The footrest is made with a 
wooden plate. There is a dummy steering in front of the coach. These are also seats for six people of $65 \mathrm{~kg}$ average each to it on.

Three-phase ( $3 \varnothing)$ Variable Electric Motor: It transmits power to the shaft at the lower end, coupled to the shaft by a plain coupling. The design is based on $5 \mathrm{hp}(22 \mathrm{rpm})$.

Remote Control Switch: This is incorporated in the power source of the variable electric motor, to enable the people on the amusement park train to stop it while merry-go-round. This has a control box and a remote switch. The box is connected in between the power source and the motor as shown in Fig.1. The signal of the remote control is based on the radio waves.

Concrete (Foundation): Concrete mix ratio; for this type of design grade 25 was employed, of ratio 1:1/2:3. This means 2 head pans of cement, 3 head pan of sand, and 6 head pans of gravel. This mix ratio design was adopted because the structure that was to be used needs to be placed underground and for it to be protected, a high mixing ratio needs to be used which makes it suitable for its purpose.

\section{Machine parts design calculation}

The Amusement park train as discussed comprises the following machine component parts; variable electric motor (5hp), Ø75 Diameter stepped shaft, base frame and housing, plain coupling, lever arm, and four-tires coach as shown in Fig. 1a to Fig 1c. The figures present the design of working drawings of the machine.

The parameters considered for the design of these machine parts include; strength, availability of materials, durability, ease of operation, type of maintenance, efficiency, and total cost of construction. Equations 1-9 from [13-15] were use to establish the power required in driving the shaft.

\section{Power Required to Drive Shaft}

Design for Power of Variable Electric Motor

Assumptions made in the design calculations include;

Radius of track - $3 \mathrm{~m}$; Load - $600 \mathrm{~kg}$; Speed -8 - 12 rpm;

$\mathrm{N}=12 \mathrm{rpm}$ design is based on maximum speed

$$
\text { Angular velocity }=\mathrm{w}=2 \pi \mathrm{N} / 60
$$

$\mathrm{w}=\alpha \mathrm{t}, \alpha=$ angular acceleration;

Assume $\mathrm{t}=5$ secs.

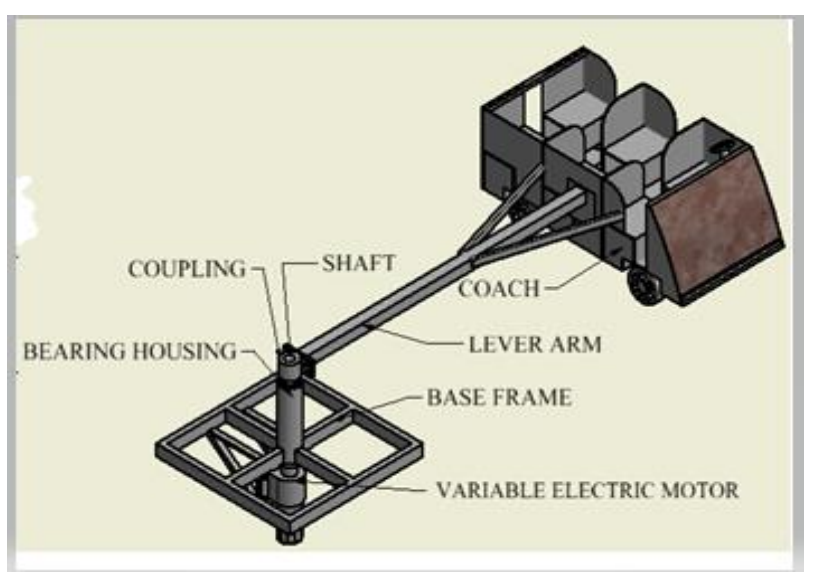

a)

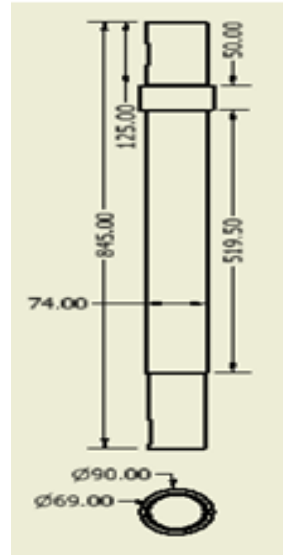

b)

Fig. 1. a) Amusement park train: a) 3-D View; b) main shat design 

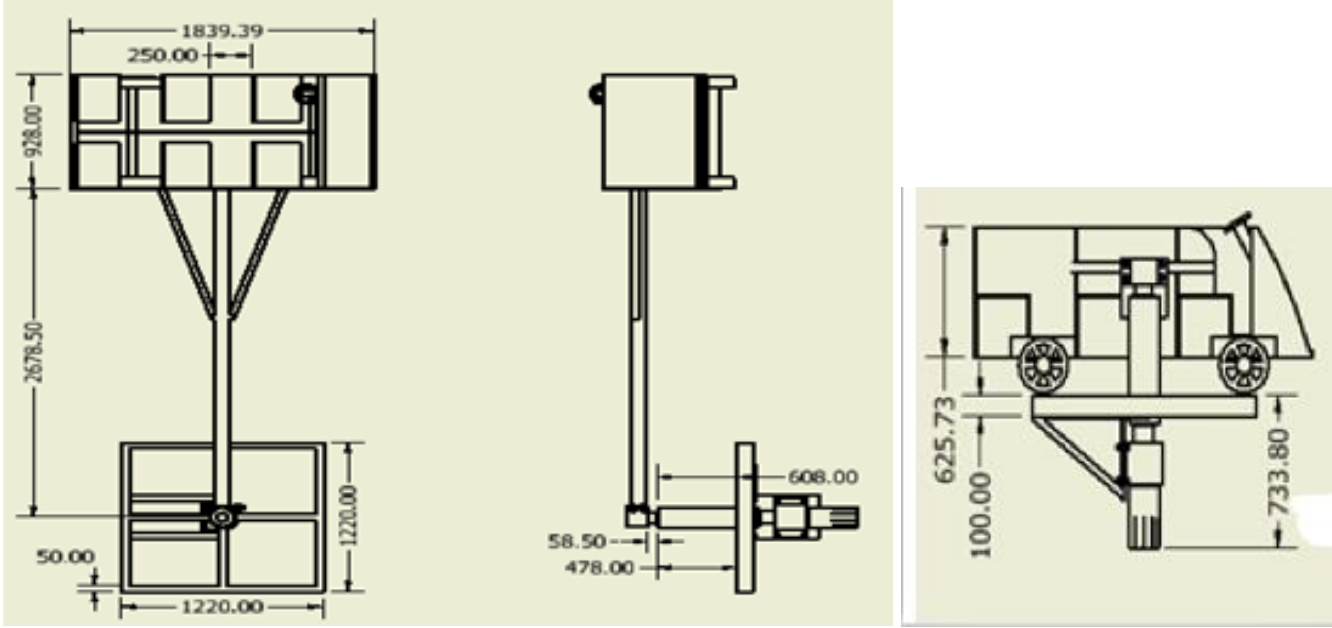

Fig. 1. Amusement park train: c) Orthographic views

Dynamic analysis and static analysis to determine co-efficient of drag force is determine based on Fig. 2.

$$
\begin{gathered}
\mu=\mathrm{F}_{\mathrm{s}} / \mathrm{mg}=0.044 \\
\mathrm{P}_{1}=\mathrm{Tw}=\mathrm{I} \alpha \mathrm{w}=\left(\mathrm{I}_{\mathrm{o}}+\mathrm{mr}^{2}\right) \alpha \mathrm{W}
\end{gathered}
$$

But $\mathrm{I}_{0}=0 ;$ mawr ${ }^{2}=$ power without the application of frictional force.

$$
\mathrm{P}_{1}=\mathrm{m \alpha wr} \mathrm{r}^{2}
$$

Power used to overcome frictional effect

$$
\mathrm{P}_{\mathrm{s}}=\mathrm{mg} \mu \mathrm{v}
$$

$$
\begin{gathered}
\text { Total Power }=\mathrm{P}_{1}+\mathrm{P}_{\mathrm{s}}=\mathrm{m} \alpha \mathrm{wr}^{2}+\mathrm{mg} \mu \mathrm{v} \\
\mathrm{P}_{\mathrm{T}}=\mathrm{m} \alpha \mathrm{wr}^{2}+\mathrm{mg} \mu \mathrm{rw}
\end{gathered}
$$

Total load of the system;

Where:

$$
\mathrm{F}=(\operatorname{mr\alpha }+\mu \mathrm{mg})=\text { dynamic load }
$$

Angular velocity $=\mathrm{W}=2 \pi \mathrm{N} / 60=24 \pi / 60=1.256 \mathrm{rad} / \mathrm{s}, \mathrm{r}=3 \mathrm{~m}$

$\mathrm{w}=\alpha \mathrm{t}^{1}, \alpha=$ angular acceleration

Assume $\mathrm{t}^{1}=5$ secs.

$\mathrm{w}=\alpha \mathrm{t}^{2}=1.256 \mathrm{rad} / \mathrm{s} /=0.25 \mathrm{rad} / \mathrm{s}^{2}$

Dynamic analysis and static analysis to determine co-efficient of drag force; $\mu=\mathrm{F}_{\mathrm{s}} / \mathrm{mg}$

Let the co-efficient of drag force between tyres and road be

$\mu=F_{\mathrm{s}} / \mathrm{mg}=0.044$

$\mathrm{a}^{\mathrm{r}}=\mathrm{w}^{2} \mathrm{r}$

$\mathrm{a}^{\mathrm{t}}=\mathrm{r} \alpha$ 
$\mathrm{P}_{1}=\tau \mathrm{w}=\mathrm{I} \alpha \mathrm{w}=\left(\mathrm{I}_{\mathrm{o}}+\mathrm{md}^{2}\right) \alpha \mathrm{w}$

But $\mathrm{I}_{0}=\mathrm{O} ; \mathrm{M} \alpha \mathrm{wd}^{2}=$ power without the application of fractional force.
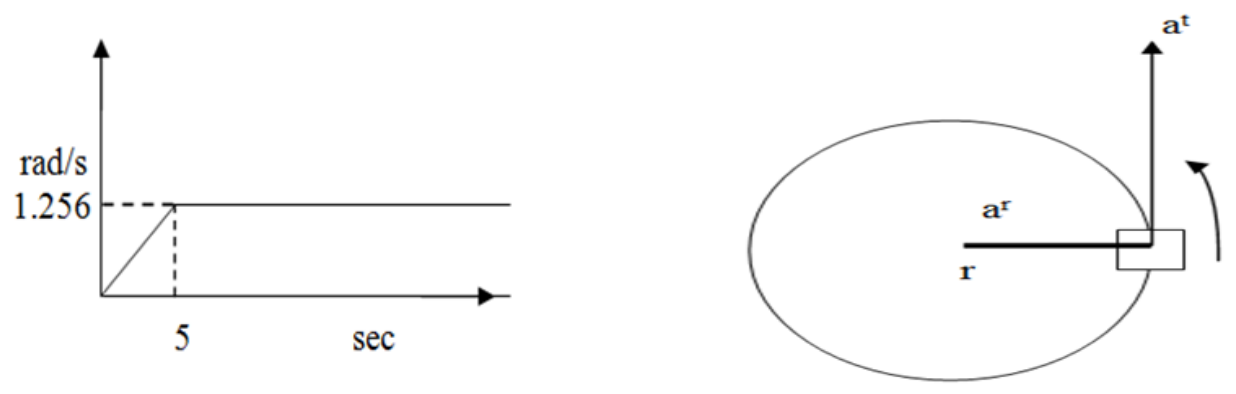

Fig. 2. Angular acceleration on circular path for the coach

$$
\mathrm{P}_{1}=\mathrm{M} \alpha w \mathrm{r}^{2}
$$

Power used to overcome frictional effect

$$
\mathrm{P}_{\mathrm{s}}=\mathrm{Mg} \mu \mathrm{V}
$$

$$
\begin{aligned}
& \mu=F_{\mathrm{s}} / \mathrm{mg}=0.044 \\
& \text { Total Power }=\mathrm{P}_{1}+\mathrm{P}_{\mathrm{s}} \\
& =\mathrm{M} \alpha \mathrm{wr}^{2}+\mathrm{Mg} \mu \mathrm{v} \\
& =\mathrm{M} \alpha \mathrm{wr}^{2}+\mathrm{Mg} \mu \mathrm{rw} \\
& \mathrm{P}_{\mathrm{T}} \quad=2678.23 \mathrm{~W}=3.59 \mathrm{hp} \text {. }
\end{aligned}
$$

Torsion moment, $\tau=2132.35 \mathrm{Nm}$.

Total load of the system; $F=(\mathrm{mr} \alpha+\mu \mathrm{mg})$

$\mathrm{F}=$ dynamic load $=710.78 \mathrm{~N}$.

Hence the power of the motor requires should not be less than $3.58 \mathrm{HP}$

\section{Shaft Design}

A shaft is a rotating or stationary member of a machine, mounted upon it are, gear, pulley, flywheel, sprocket, and other power transmission elements. The shaft may be subjected to; bending; tension; compression or torsion load [16,17].

The power transmission element used in this machine is plain coupling, located close to the supporting bearing so as to reduce the bending moment, deflection, and bending stresses. This shaft design is influenced by two main factors; bending and torsion moment as shown in Fig. 3 to 7 . The shaft rotates vertically, which means the design will be based on torsion moment alone $[5,11,12,15,16]$.

Torsion moment acting on vertically rotating shaft is given by;

Where:

$$
\mathrm{M}_{\mathrm{t}}=9550 \mathrm{x \textrm {kW }} / \mathrm{rev} / \mathrm{min}
$$

$\mathrm{M}_{\mathrm{t}}=9550 \mathrm{x} \mathrm{kW} \mathrm{Nm} / \mathrm{rev} / \mathrm{min}$

Total power $\mathrm{P}_{\mathrm{T}}=2678.23 \mathrm{~W}$ from power analysis

$\mathrm{M}_{\mathrm{t}}=2131.4 \mathrm{Nm}, \mathrm{SyP}=220 \mathrm{MN} / \mathrm{m}^{2} \mathrm{~N}=3$

For solid shaft 


$$
\tau=\mathrm{M}_{\mathrm{t}} \mathrm{r} / \mathrm{J}=16 \mathrm{M}_{\mathrm{t}} / \pi \mathrm{d}^{3}=\operatorname{SyP} / 2 \mathrm{~N}
$$

Torsion moment $=32 \mathrm{M}_{\mathrm{t}} / \pi \mathrm{d}^{3}=\mathrm{SyP} / \mathrm{N}=0.0666 \mathrm{~m}=66.65 \mathrm{~mm}$.

The designed diameter for the shaft is $66.65 \mathrm{~mm}$ but a diameter of $80 \mathrm{~mm}$ can be chosen for safety under higher load.
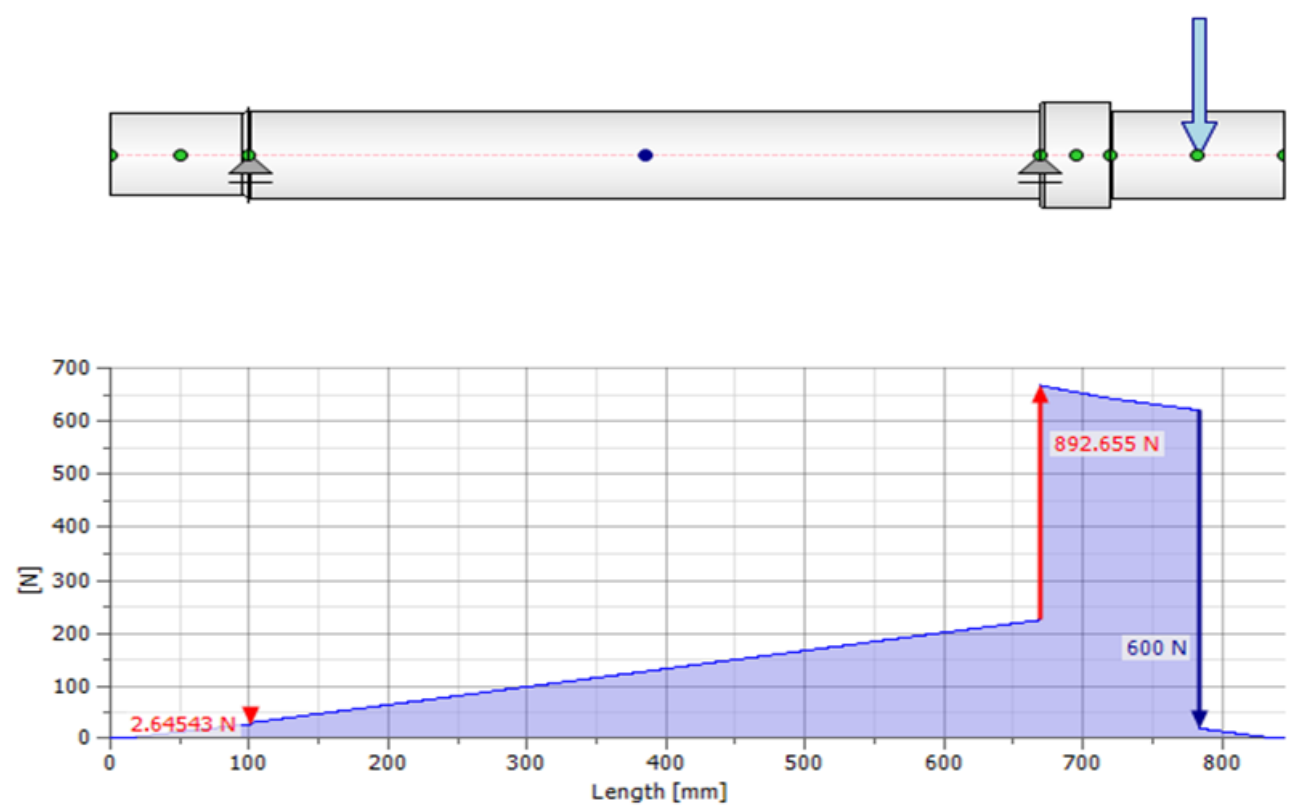

Fig. 3. Shear force graph

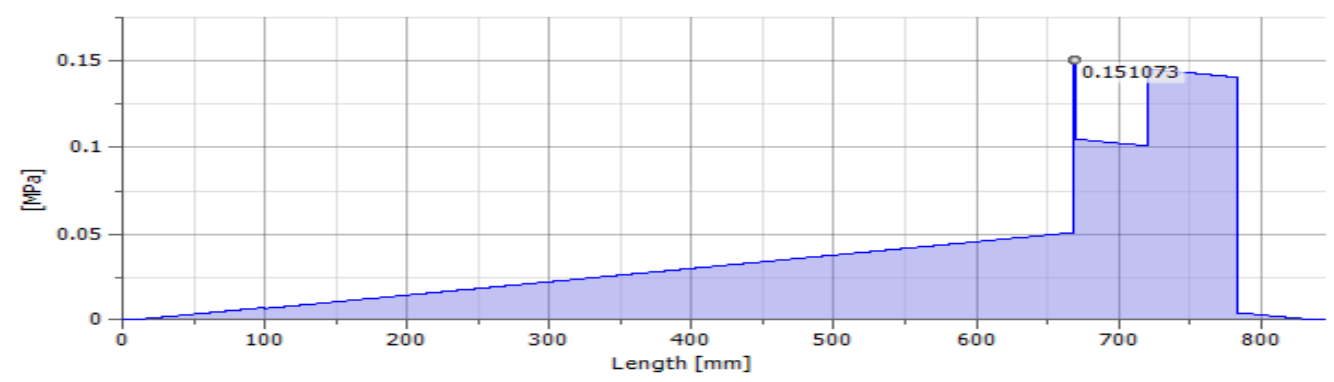

Fig. 4. Shear stress graph 

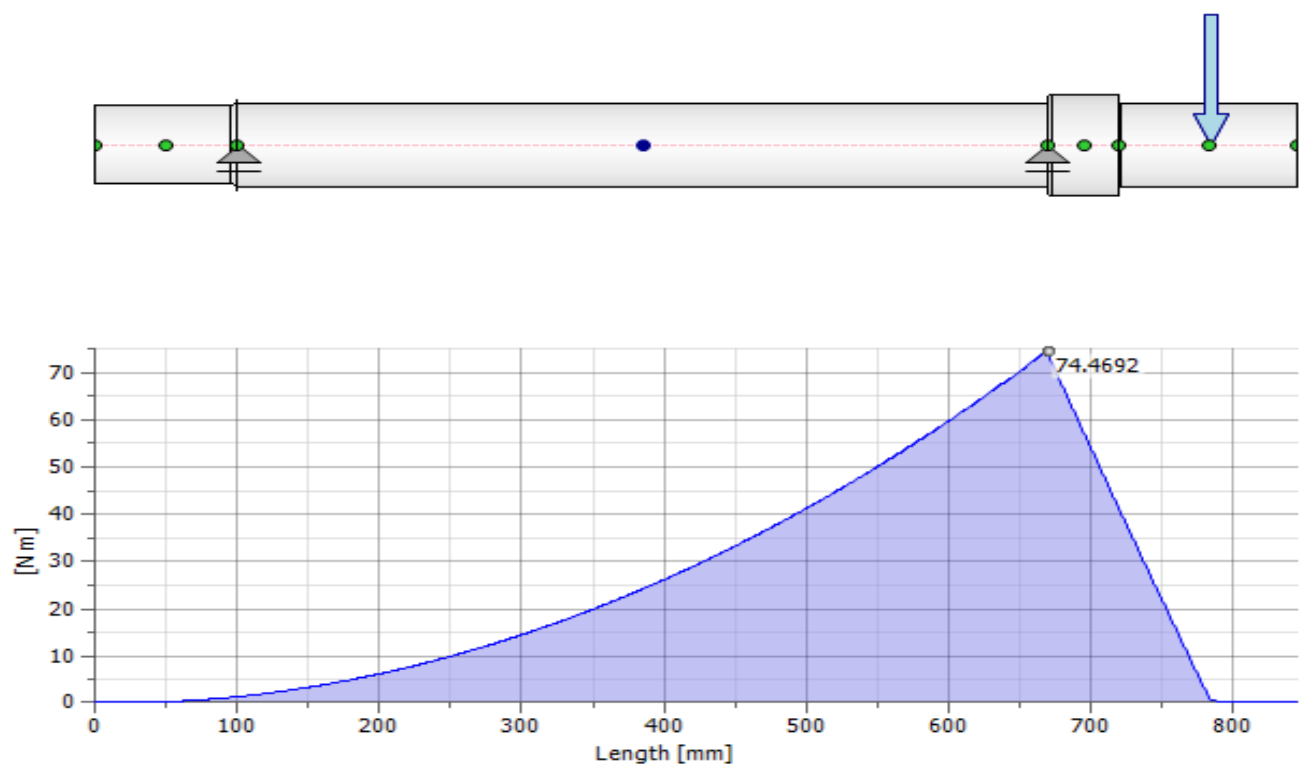

Fig. 5. Bending moment graph
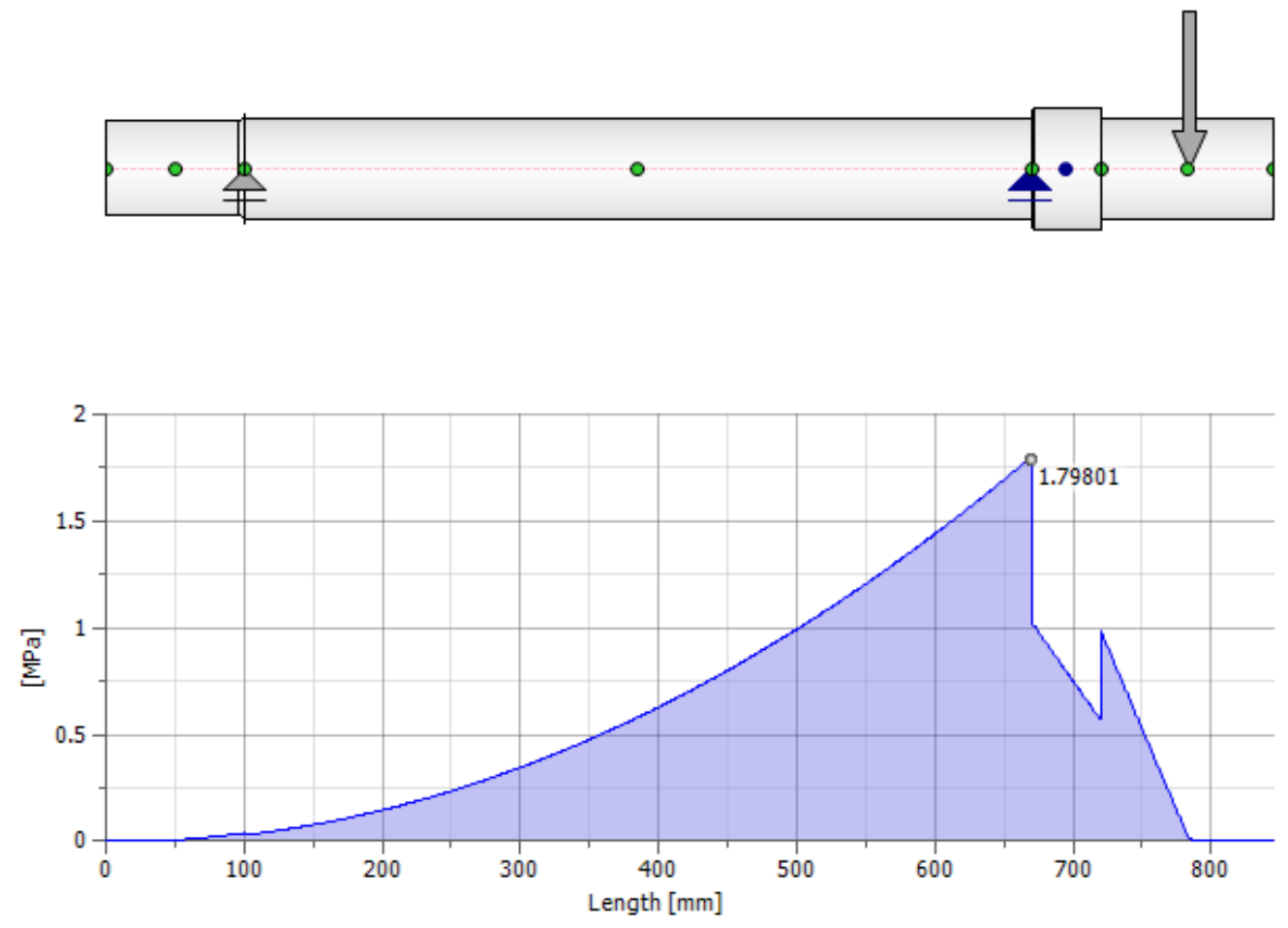

Fig. 6. Bending stress graph 


\section{Arm Design}

Assumptions;

- It was assumed that the arm is lying horizontally and perpendicular to the coach, which is the line of action of the force.

- The arm I loaded at one end.

- Bending and transverse shear stresses are the stresses on the arm.

- Transverse shear stress is negligible $[11,12]$.

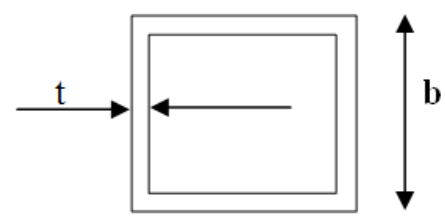

Fig. 7. Front view of square steel tube

$\delta_{\mathrm{x}}=\mathrm{Mc} / \mathrm{I}+\mathrm{P} / \mathrm{A}$ but axial load is negligible

$\mathrm{P} / \mathrm{A}=0$

$\delta_{\mathrm{x}}=\mathrm{Mc} / \mathrm{I}$

$\mathrm{b}=\mathrm{h}$, let $\mathrm{b} 8 \mathrm{t}, \mathrm{c}=4 \mathrm{t}$

$\mathrm{I}=\mathrm{bh}^{3} / 12-(\mathrm{b}-2 \mathrm{t})^{4} / 12$

$\mathrm{b}=8 \mathrm{t}$

$\mathrm{I}=\frac{2880 \mathrm{t}^{4}}{12}$

$\mathrm{I}=233.3 \mathrm{t}^{4}$.

$\delta_{\mathrm{w}}=\frac{\mathrm{SyP}}{\mathrm{N}}=73.33 \mathrm{MN} / \mathrm{m}^{2}$

$\delta_{\mathrm{x}}=\mathrm{Mc} / \mathrm{I}$

$\delta_{\mathrm{x}}=\delta_{\mathrm{w}}=73.33 \mathrm{MN} / \mathrm{m}^{2}$

$\mathrm{t}=6.8 \mathrm{~mm}$

Now if $\mathrm{t}=6 \mathrm{~m}$ and $\mathrm{b}=90 \mathrm{~mm}$

$\mathrm{I}=233.3 \mathrm{t}^{4}$ when $\mathrm{t}=6.8 \mathrm{~mm}$,

$\mathrm{I}=498827.5 \mathrm{~mm}^{4}$

Deflection of hollow beam

$\mathrm{I}=\underline{\mathrm{FL}^{3}} \quad \mathrm{E}=210 \times 10^{9} \mathrm{~N} / \mathrm{m}^{2}$

$\mathrm{F}=\mathrm{Ma}^{\mathrm{t}}=\mathrm{mr} \alpha$

$\delta=\mathrm{mr \alpha l}^{3} / 3 \mathrm{EI}$, when $\mathrm{I}=498827.5 \mathrm{~mm}^{4}$

$\delta=0.0252 \mathrm{~m}=25.2 \mathrm{~mm}$

When $\mathrm{I}=2.382913 \times 10^{-6} \mathrm{~m}^{4}$

$\delta=0.005289 \mathrm{~m}=52.89 \mathrm{~mm}$

\section{Plain Coupling Design}

Couplings are used to connect sections of a shaft or to connect the shaft of a driving machine to the shaft of a driving machine. The coupling may be rigid or flexible depending on the speed of the shaft. It is desirable to provide for good alignment and location of the coupling where the bending moment is practically zero, thus for rigid coupling as well as flexible coupling analysis is based on torsion only [17-20].

Torsional stress $=\mathrm{I}_{\max }=16 \mathrm{M}_{\mathrm{t}} \mathrm{d}_{0} / \pi\left(\mathrm{d}_{0}{ }_{0}-\mathrm{d}_{1}{ }^{4}\right)$

for hollow shaft $=\mathrm{I}_{\max }=\mathrm{SyP} / 2 \mathrm{~N}>16 \mathrm{MtD}_{0} / \pi\left(\mathrm{D}_{0}{ }^{4}-\mathrm{D}_{1}{ }^{4}\right)$ 
$\mathrm{D}_{0}=$ outer diameter of the coupling

$\mathrm{D}_{1}=$ inner diameter of the coupling $=0.0666 \mathrm{~m}$

Diameter of the main shaft

$\mathrm{SyP}=220 \mathrm{MN} / \mathrm{m}^{2}, \mathrm{~N}=3$

$220 / 2 \times 3=16 \mathrm{D}_{\mathrm{o}} \times 2132.35 / \pi\left(\mathrm{D}_{0}{ }^{4}-0.0666^{4}\right)$

$3376.75 \mathrm{D}_{0}^{4}-0.066643=\mathrm{D}_{\mathrm{o}}$

$D_{n}=$ Let $D_{0}=0, n=1,2,3$ etc., using successive iteration

$\mathrm{D}_{1}=0.0666 \mathrm{~m}$

$\mathrm{D}_{2}=0.07922 \mathrm{~m}$

$\mathrm{D}_{3}=0.08103 \mathrm{~m}$

$\mathrm{D}_{4}=0.08125 \mathrm{~m}$

$\mathrm{D}_{5}=0.08103 \mathrm{~m}$

$\mathrm{D}_{0}=$ outer diameter of the coupling which shaft $=0.08103 \mathrm{~m}=81.3 \mathrm{~mm}$.

\section{Power Transmission}

The power transmission unit consists of a plain coupling assembly system, converting vertical shaft rotational motion to translational motion through a connection called the lever arm, to move the coach round the circle (merry-go-round) as shown in Fig. 9. The power is derived from variable electric motor via plain coupling also to vertical shaft and to lever arm via plain coupling (sleeve) and finally to transnational motion via fastener between the coach and the lever arm. This is a simple power transmission system $[15,18]$.

\section{Remote Control Switch}

This is incorporated in the power source of the variable electric motor, to enable the people on the amusement park train to stop it while merry-go-round. This has a control box and a remote switch. The box is connected between the power source and the motor. The signal of the remote control is based on the radio waves as presented in Fig. 8.

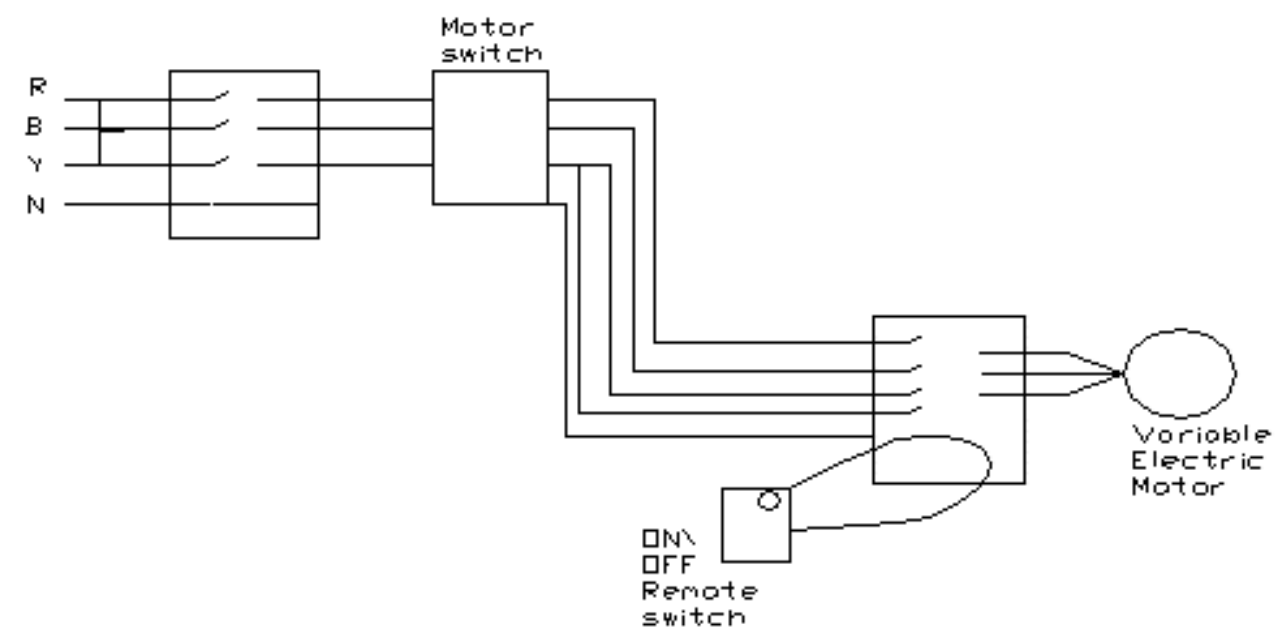

Fig. 8. Electrical circuit and remote-control units 


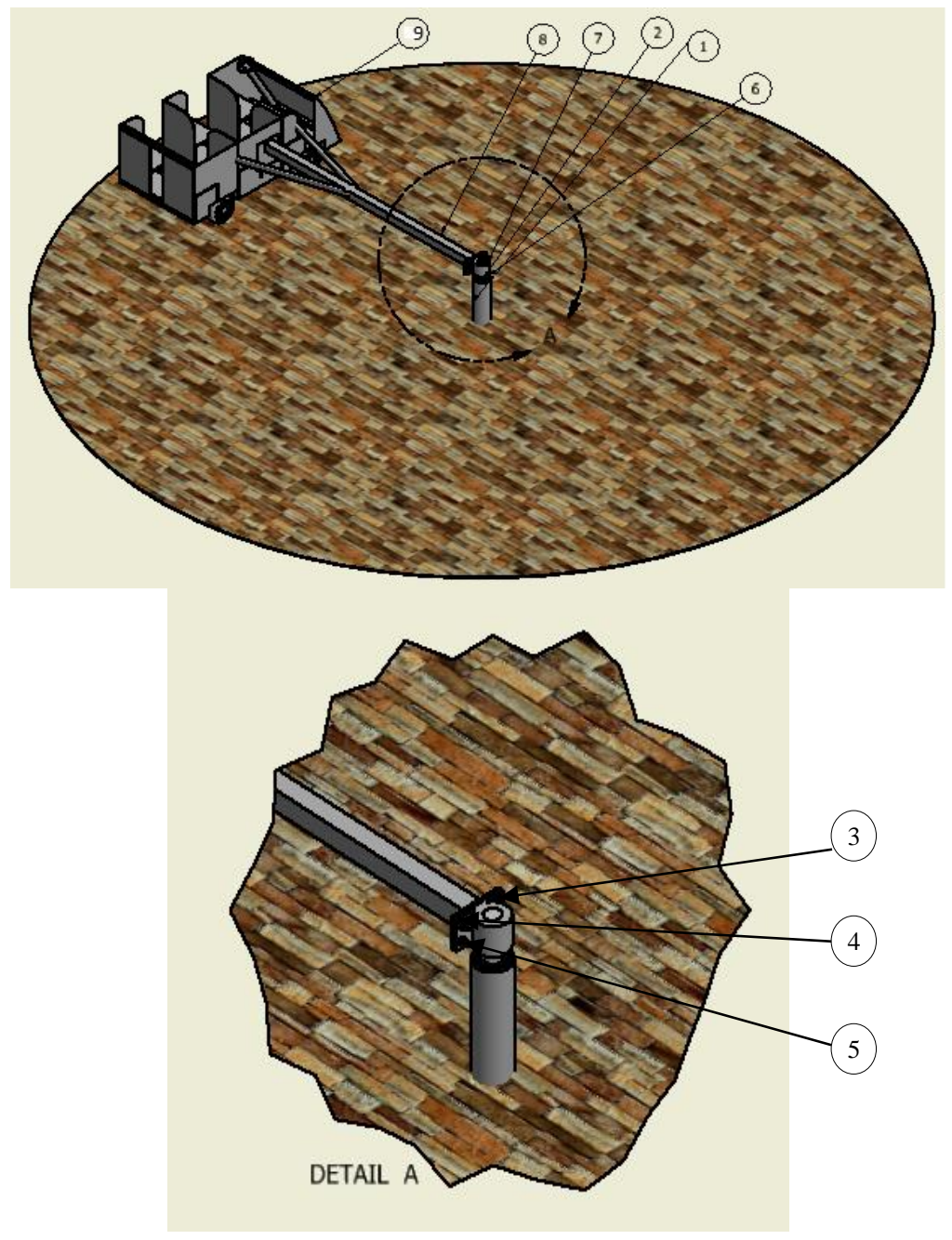

Fig. 9. Isometric working diagram with part list table Table 1. Amusement park train - part list

\begin{tabular}{|c|c|c|}
\hline Item & Quantity & Part number \\
\hline 1 & 1 & Base frame and bearing housing \\
\hline 2 & 2 & Shaft \\
\hline 3 & 4 & ANSI B 18.2.3.4M -M14x2x55 \\
\hline 4 & 4 & ASME B18.12.2M - 14 \\
\hline 5 & 5 & ANSI B18.2.4.M - M12 x 2 \\
\hline 6 & 2 & $\begin{array}{l}\text { BS 3134: Part } 2-3 \mathrm{CC}- \\
90 \times 140 \times 32\end{array}$ \\
\hline 7 & 1 & Coupling \\
\hline 8 & 1 & Lever arm \\
\hline 9 & 1 & Coach \\
\hline
\end{tabular}

Mild steel Description
Mild steel
Metric hex
Flange screw
Lock washers (metric series) Regular helical
Spring lock
Washers
Metric hex
Flange nuts
Metric tapered roller bearing - Specification for dimensions of
double row bearing. Double Row
Mild steel
Square pipe ( $90 \mathrm{~mm}$ x $90 \mathrm{~mm}$ x $5 \mathrm{~mm}$ )
Mild steel




\section{Result and Discussion}

The fabricated amusement park train as shown in Fig. 10 was tested for efficiency. It was connected to a power source and loaded with six passengers carrying capacity of $600 \mathrm{~kg}$ to confirming that the developed machine is working as expected. It was operated for some time to inspect its operational conditions such as load against speed. The weight of the arm and the coach is measured to be $90.2 \mathrm{~kg}$ with the aid of helical spring. Also, static friction and dynamic friction were determined with no load against the force applied to helical spring to overcome the frictions. For successive additional load, forces to overcome static and dynamic frictions were measured and recorded and compared as presented in Fig. 11.

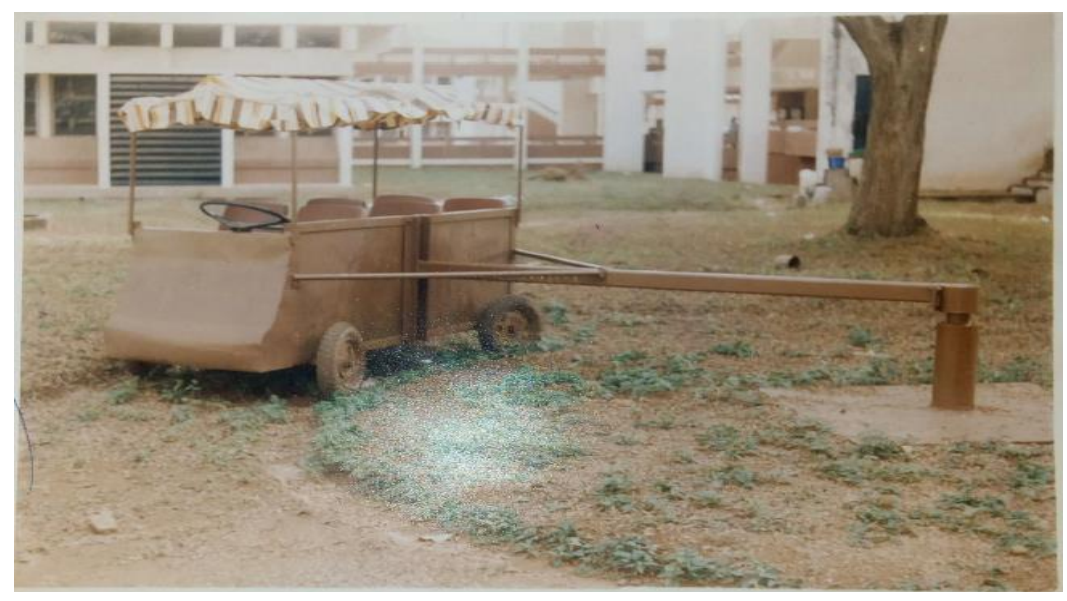

Fig. 10. Developed amusement park train

\section{Experimental test of the system}

The following tests were carried out on the developed amusement park train to examined the carrying capacity of the machine and the speed of operation as shown in Plate 1. The result of the test carried out on the amusement park train is presented in Fig. 11 and 12.

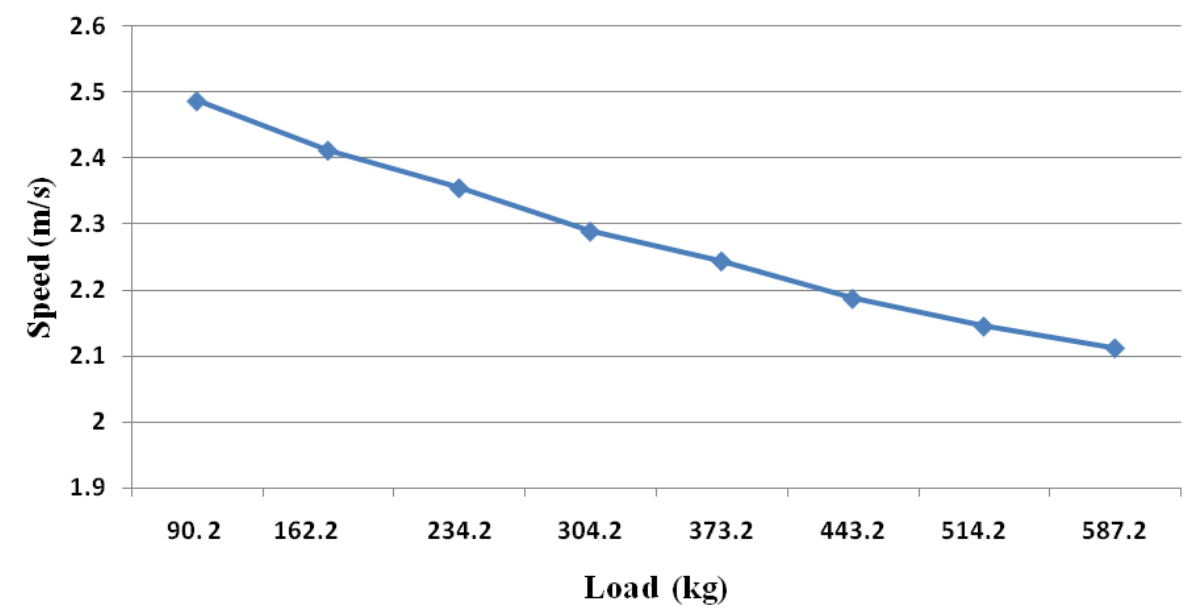

Fig. 11. Speed of operation $(\mathrm{m} / \mathrm{s})$ against load $(\mathrm{kg})$ 


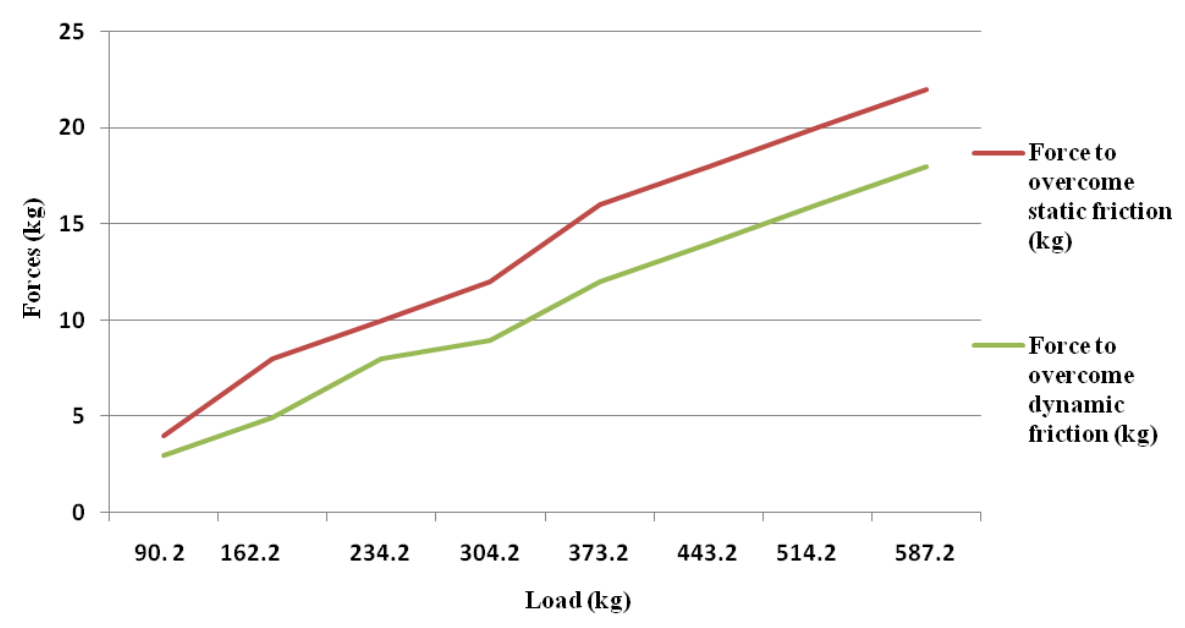

Fig. 12. Force to overcome static friction and dynamic friction against load $(\mathrm{kg})$

\section{Performance Evaluation of the system}

From the design analysis, the power requires to move $600 \mathrm{~kg}$ is determined from

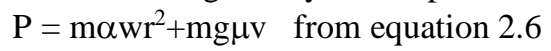

Total power $=3.59 \mathrm{hp}$

$\mathrm{P}_{\mathrm{T}}=$ Power Designed for 2678. 23W $=3.59 \mathrm{hp}$

From the graph of velocity against load, using (Figure 10) the rated velocity $=2.487 \mathrm{~m} / \mathrm{s}$.

From $\mathrm{F}=\mu \mathrm{mg}$

Power $=\mathrm{P}_{1}=\mathrm{Fv}=\mu \mathrm{mgv}$

$\mathrm{F}=\mathrm{m} \alpha \mathrm{wr} \mathrm{r}^{2}=\operatorname{m\alpha rv}=\mathrm{P}_{2}$

The estimated power from rated velocity and analysis: $\mu \mathrm{mgv}+\mathrm{m} \alpha \mathrm{rv}=\mathrm{P}_{1}+\mathrm{P}_{2}$

Efficiency \%: Estimated power analysis/ Power Designed for $=67.69 \%$.

The amusement park train is a viable design, very strong, and efficient $[12,15]$.

\section{System Operational Safety Precautions}

1. The system must be properly mounted to avoid vibration.

2. The appropriate fastener must be selected for a particular joint operation

4. Electrical cables and connections must be properly insulated to prevent shock while the system in operation.

\section{Conclusion}

The objectives of this project are achieved. It has a capacity to carrying a $600 \mathrm{~kg}$ total load in the coach and moving at $2.2 \mathrm{~m} / \mathrm{s}$ around the track (merry-go-round). The operation is a remote control and it is very safe for the user and operator. The efficiency of the amusement park train is $67 \%$, which is a good result.

\section{References}

[1] Bigné, J. E., Andreu, L. and Gnoth, J. The theme park experience: An analysis of pleasure, arousal, and satisfaction, Tourism Management, 26 (6), 2005, pp. 833-844

[2] Ellen, C. D., Jon, B. B., Trisha, M. and Paul, N. Theme Park Queue Line Perception, International Journal of Cultural Heritage, 2, 2017, pp. 105-118, ISSN: 2367-9050 
[3] Trischler, J. and Zehrer, A. Service design: Suggesting a qualitative multistep approach for analyzing and examining theme park experiences, Journal of Vacation Marketing, 18 (1), 2012, pp. 57-71

[4] Theodoropoulou, E. and Kaldis, P. Changes in rural areas and regional development, Journal of Social Sciences, 4(4), 2008, pp. 275-279

[5] Maliki, O.B., Ejiko, S.O. and Ajewole P. Design and Fabrication of Maize Roasting Machine, $7^{\text {th }}$ Engineering Forum, School of Engineering, The Federal Polytechnic, Ado-Ekiti, 2011, pp 7-11

[6] McClung, G. W. Theme park selection: factors influencing attendance, In R. Ryan, \& S. Page (Eds.). Tourism management. Towards the new millennium. Advances in tourism research series 2000, pp. 233-245 Oxford: Elsevier Science.

[7] Ejiko, S. O, Oigbochie D. and Adewuyi R. A. Development of an Engine Block Polishing Machine Using Locally Sourced Material, International Journal of Scientific Engineering and Science, 2(5), 2018, pp. 32-36

[8] Steven R. S., Bernard J. H. and Jacobson B. O. Fundamentals of Machine Elements, 2013, Third Edition pp. 626

[9] Peter R.N. Childs, Mechanical Design Engineering Handbook Book, 2019, Second Edition pp. 145-165

[10] Power Distribution Systems Design Guide SA081002EN Effective February 2019

[11] Hall A. S., Holowenko A. R. and Laughlin A. G., Theory and Problems of Machine Design, Schaums Outline Series, New Delhi: Tata McGraw-Hill, Fifth reprint, 2011

[12] Gope, P. C. Machine Design Fundamentals and Applications, Technology \& Engineering, PHI Learning Pvt. Ltd, 2012, pp. 1312

[13] Rucks, C. T., and Geissler, G. L. The overall theme park experience: A visitor satisfaction tracking study, Journal of Vacation Marketing, 17(2), 2011, pp. 127-138, DOI: $10.1177 / 1356766710392480$

[14] Oigbochie, D. and Ejiko, S. O. Modification of a Motorized Quadcycle, International Journal of Scientific \& Engineering Research (IJSER), 6(9), 2015, pp. 87-95

[15] Rajput, R. K. Strength of Materials, 24th Ed., S. Chand and Cotta, New Delhi. 2006

[16] Ejiko, S. O., Adu, J. T. and Osayemi, P. Design and Fabrication of Groundnut Shelling Machine, Grin Research Journal, Germany, 2015, https://m.grin.com/document/306848

[17] Ejiko S. O., Adu J. T. and Owolabi H. A. Development and Evaluation of a Drill Re-grinding Fixtur, Nigerian Journal of Technology (NIJOTECH), 36(2), 2017, pp. 437-443

[18] Bhandari, V.B. Design of Machine Elements, New Delhi: Tata McGraw Hill Education Private Limited, 2010, pp. 330-334

[19] Shigley J.E and Mischke C.R. Mechanical Engineering design, Fifth Edition, MCGRAW AILL, Inc. California. 1989, pp 24 - 25, pp. $714-724$

[20] Ejiko S. O., Oigbochie D. and Emmanuel A. A. Design of A Semi Mechanize Gari Fryer IOSR Journal of Mechanical and Civil Engineering, 15(2), 2018, pp. 23-30

Received: November 30, 2020

Accepted: January 05, 2021 